\title{
Detrimental effect on the gut microbiota of 1,2-dicarbonyl compounds after in vitro gastro-intestinal and fermentative digestion
}

Article

Accepted Version

Creative Commons: Attribution-Noncommercial-No Derivative Works 4.0

Brighina, S., Poveda Turrado, C., Restuccia, C., Walton, G., Fallico, B., Oruna-Concha, M. J. ORCID:

https://orcid.org/0000-0001-7916-1592 and Arena, E. (2021) Detrimental effect on the gut microbiota of 1,2-dicarbonyl compounds after in vitro gastro-intestinal and fermentative digestion. Food Chemistry, 341. 128237. ISSN 0308-8146 doi: https://doi.org/10.1016/j.foodchem.2020.128237 Available at https://centaur.reading.ac.uk/93261/

It is advisable to refer to the publisher's version if you intend to cite from the work. See Guidance on citing.

To link to this article DOI: http://dx.doi.org/10.1016/j.foodchem.2020.128237

Publisher: Elsevier

All outputs in CentAUR are protected by Intellectual Property Rights law, including copyright law. Copyright and IPR is retained by the creators or other copyright holders. Terms and conditions for use of this material are defined in the End User Agreement. 


\section{www.reading.ac.uk/centaur}

\section{CentAUR}

Central Archive at the University of Reading

Reading's research outputs online 


\section{Journal Pre-proofs}

Detrimental effect on the gut microbiota of 1,2-dicarbonyl compounds after in vitro gastro-intestinal and fermentative Digestion

Selina Brighina, Carlos Poveda Turrado, Cristina Restuccia, Gemma Walton, Biagio Fallico, Maria Jose Oruna-Concha, Elena Arena

PII: S0308-8146(20)32099-9

DOI: https://doi.org/10.1016/j.foodchem.2020.128237

Reference: FOCH 128237

To appear in:

Food Chemistry

Received Date:

4 June 2020

Revised Date: 25 September 2020

Accepted Date: 25 September 2020

Please cite this article as: Brighina, S., Poveda Turrado, C., Restuccia, C., Walton, G., Fallico, B., Jose OrunaConcha, M., Arena, E., Detrimental effect on the gut microbiota of 1,2-dicarbonyl compounds after in vitro gastro-intestinal and fermentative Digestion, Food Chemistry (2020), doi: https://doi.org/10.1016/j.foodchem. 2020.128237

This is a PDF file of an article that has undergone enhancements after acceptance, such as the addition of a cover page and metadata, and formatting for readability, but it is not yet the definitive version of record. This version will undergo additional copyediting, typesetting and review before it is published in its final form, but we are providing this version to give early visibility of the article. Please note that, during the production process, errors may be discovered which could affect the content, and all legal disclaimers that apply to the journal pertain.

(C) 2020 Published by Elsevier Ltd. 


\section{Detrimental effect on the gut microbiota of 1,2-dicarbonyl}

\section{compounds after in vitro gastro-intestinal and fermentative}

\section{digestion}

Selina BRIGHINA a, Carlos POVEDA TURRADO b, Cristina RESTUCCIA a, Gemma WALTON $^{\mathrm{b}}$, Biagio FALLICO ${ }^{a *}$, Maria Jose ORUNA-CONCHA $^{\mathrm{b}}$, Elena ARENA ${ }^{\mathrm{a}}$

a) Dipartimento di Agricoltura, Alimentazione e Ambiente (Di3A), Università degli Studi di Catania (Italy). Polo Bioscientifico, Via S. Sofia 98-100, 95123, Catania (Italy).

b) Department of Food and Nutritional Sciences, University of Reading (United Kingdom), PO Box 226, Whiteknights, Reading (UK), RG6 6AP.

*, Corresponding author: biagio.fallico@unict.it

Selina BRIGHINA: selina.brighina@unict.it; Cristina RESTUCCIA:

cristina.restuccia@unict.it; Carlos POVEDA TURRADO:

c.g.povedaturrado@reading.ac.uk; Gemma WALTON: g.e.walton@reading.ac.uk; Maria Jose ORUNA-CONCHA: m.j.oruna-concha@reading.ac.uk; Elena ARENA: elena.arena@unict.it.

Highlights:

- GO, MGO and 3-DG withstand in vitro gastrointestinal digestion

- Digested 1,2-dicarbonyl compounds reduce number and activity of gut microorganisms

- For the first time, the role of 3-DG in modifying the gut microbial levels has been shown 
- 1,2-dicarbonyls reduce the levels of Short Chain Fatty Acids produced during fermentation 


\section{Abstract}

This study, investigated the stability of dicarbonyl compounds (DCs), 3-deoxyglucosone (3-DG), glyoxal (GO) and methylglyoxal (MGO) during simulated gastrointestinal digestion processes and the impact these compounds have on the gut microbiota. DCs pass almost unaltered through the in-vitro gastrointestinal digestion phases (concentration loss: $11 \%$ for $3-\mathrm{DG}, 24 \%$ for GO and MGO) and have an effect on the fermentative digestion process, reducing the total gut bacterial population up to $6 \log _{10}$ units. Previous studies have shown no antimicrobial activity for 3-DG, however, for the first time it has been shown that when incubated with faecal bacteria 3-DG strongly depressed this microbial community.

The influence of dicarbonyl compounds on the anaerobic fermentation processes was confirmed by the reduced production of short-chain fatty acids. Considering the modern Western diet, characterised by high consumption of ultra-processed foods rich in dicarbonyl compounds, this could lead to a reduction of bacteria important for the microbiome.

\section{Keywords}

3-deoxyglucosone; methylglyoxal, glyoxal; gut microbiota; short-chain-fatty-acids; antimicrobials. 


\section{Introduction}

The human gut is colonised by an enormous number of microorganisms, mainly bacteria and, it is estimated that the microbiota of a human adult is composed of $\sim 10^{14}$ bacterial cells (Zhu, Wang \& Li, 2010). The composition, as well as the ratio of different species forming the intestinal microbiome, is very diverse within the human population (Dicksved, 2008) and influenced by multiple factors, such as age, origin, environment and dietary habits. Owing to the multitude of direct and indirect interactions with the host organism, the intestinal microbiome is closely linked to host health (Saarela, Lähteenmäki, Crittenden, Salminen \& Mattila-Sandholm, 2002; Del Rio, Rodriguez-Mateos, Spencer, Tognolini, Borges \& Crozier, 2013).

Several studies have investigated the impact of diety nutraceuticals on the microbiota, such as polyphenols, prebiotics and polyunsaturated fatty acids (Duda-Chodak, Tarko, Satora \& Sroka, 2015 and references therein).

Within diet-derived compounds, particular attention has to be paid to reactive 1,2dicarbonyl compounds, including methylglyoxal (MGO), glyoxal (GO) and 3deoxyglucosone (3-DG), which are formed during the early stage of Maillard reaction and/or through degradation of carbohydrates present in foods and beverages by processing, cooking and prolonged storage (Adams et al., 2008; Arena, Ballistreri \& Fallico, 2011; Arena, Ballistreri, Tomaselli \& Fallico, 2011; Degen, Hellwig, Henle, 2012; Hellwig, Gensberger-Reigl, Henle, Pischetsrieder, 2018). These carbonyl compounds can undergo several different subsequent reactions, providing a great number of secondary products, including Advanced Glycation End-products (AGEs). This term is used to describe a heterogeneous group of compounds that are formed through a series of non-enzymatic reactions. Excessive consumption of AGEs are thought to be associated with several negative health effects, which is an emerging concern for 
processed food industries (Sharma, Kaur, Thind, Singh \& Raina, 2015; Snelson \& Coughlan, 2019).

To the best of our knowledge, there is no data in the literature demonstrating the effect of pure dicarbonyl compounds on the composition of the gut microbiota and there is conflicting evidence regarding the impact of dietary dicarbonyl compounds, mainly from Manuka honey, on the composition of the gut microbiota. The ability of Manuka honey, characterised by antibacterial activity, is at least in part due to reactive MGO content, which is up to 100-fold higher than in conventional honey (Adams et al., 2008; Mavric, Wittmann, Barth \& Henle, 2008). Consumption of Manuka honey has resulted in increased numbers of beneficial gut bacteria, including Lactobacillus rhamnosus and Bifidobacterium lactis. This effect was considered particularly advantageous because, in proportion to the increasing number of positive bacteria, the number of potentially pathogenic microorganisms in the intestine decreased (Rosendale et al., 2008). Rosendale et al. (2016) also affirmed that consumption of Manuka honey, which contains antimicrobial MGO, does not significantly perturb the microbiota in the hindgut of mice, but instead resulted in the production of beneficial microbial metabolites, in particular, short-chain fatty acids.

The antibacterial activity of the three 1,2-dicarbonyl compounds (3-DG, GO and MGO) against many bacterial strains has been evaluated (Jay, Rivers \& Boisvert, 1983; Mavric et al., 2008; Blair, Cokcetin, Harry \& Carter, 2009; Hayashi, Fukushima, Hasyashi-Nishino \& Nishino, 2014; Brighina, Restuccia, Arena, Palmeri \& Fallico, 2020). These studies have demonstrated antibacterial activity of GO and MGO, while no growth inhibition was detected for 3-DG. MGO showed higher antibacterial activity than GO. Moreover, Brighina et al. (2020) demonstrated interactions between the dicarbonyl compounds, in particular MGO, and the nutrient compounds of the culture medium, highlighting that the Minimal 


\section{Journal Pre-proofs}

Inhibitory Concentration (MIC) values for microorganisms, under the studied conditions, could be significantly altered.

For the reasons mentioned above, the present study aimed to evaluate the effect of pure dicarbonyl compounds on the gut microbiota. Different concentrations of 3-DG, GO and MGO were first subjected to simulated gastrointestinal digestion, then to a $\mathrm{pH}$ controlled, anaerobic, faecal batch-culture fermentation, simulating the environmental conditions located in the distal region of the human large intestine. Changes in the bacterial population were investigated by fluorescence in situ hybridisation (FISH) and short-chain fatty acid (SCFA) analysis.

\section{Material and methods}

\subsection{Chemicals}

All reagents, unless otherwise stated, were from Sigma Aldrich (St. Louis, MO, USA); Glyoxal (GO; bioreagent $40 \%$ in $\mathrm{H}_{2} \mathrm{O}$ ) Methylglyoxal (MGO; $40 \%$ in $\mathrm{H}_{2} \mathrm{O}$ ). 3deoxyglucosone (3-DG; purity 95\%) was from Santa Cruz Biotechnology, Inc. (Dallas, TX, USA). All nucleotide probes used for fluorescent in situ hybridisation (FISH) were from Eurofins, (Birmingham, UK).

\subsection{Simulated Gastrointestinal Digestion (SGD)}

Simulated digestion method includes the oral, gastric and small intestinal phases and was used to assess the fraction of the studied molecule that passes to the anaerobic phases. Simulated digestion of 1,2-dicarbonyl compounds (DCs) was performed according to Mills et al. (2008), with slight modifications.

Water-based solutions for each of the three DCs (3-DG, MGO and GO) were prepared. $7.5 \mathrm{~g}$ of each DC aqueous solution was diluted in water $(3.75 \mathrm{~mL})$ and the mixture was stomached for $2 \mathrm{~min}$. The sample solution was transferred into a glass screw- 
topped bottle, mixed with $\alpha$-amylase $(1 \mathrm{mg})$ in $\mathrm{CaCl}_{2}(0.001 \mathrm{mmol} \mathrm{L}-1, \mathrm{pH} 7.0 ; 312.5 \mu \mathrm{L})$ and incubated at $37^{\circ} \mathrm{C}$ for $30 \mathrm{~min}$. After, the $\mathrm{pH}$ was decreased to 2.0 with $6 \mathrm{~mol} \mathrm{~L}^{-1} \mathrm{HCl}$ and pepsin $(135 \mathrm{mg})$ dissolved in $\mathrm{HCl}\left(0.1 \mathrm{~mol} \mathrm{~L}^{-1} ; 1.25 \mathrm{~mL}\right)$. The sample was incubated at $37^{\circ} \mathrm{C}$ for $2 \mathrm{~h}$. Then the $\mathrm{pH}$ was increased to 7.0 with $6 \mathrm{~mol} \mathrm{~L}^{-1} \mathrm{NaOH}$, pancreatin (28 $\mathrm{mg})$ bile $(175 \mathrm{mg})$ in $\mathrm{NaHCO}_{3}(0.5 \mathrm{~mol} \mathrm{~L}-1 ; 6.25 \mathrm{~mL})$. The sample solution was incubated at $37^{\circ} \mathrm{C}$ for $3 \mathrm{~h}$.

Finally, the samples were centrifuged at $11,620 \mathrm{~g}$ for 10 minutes and an aliquot of the supernatant was filtered through a $0.45 \mu \mathrm{m}$ filter (Albet) and derivatised (as detailed in section 2.6) before DCs HPLC analysis.

\subsection{Faecal sample collection and preparation}

Faecal samples were collected from three different donors ( 1 male, 2 female, aged 25-40 year). All donors were in good health and had not ingested any antibiotics for at least 6 months before the study. Samples were collected on the morning of the experimental fermentation. The volunteers were asked to provide these in an anaerobic jar (AnaerojarTM 2.5L, Oxoid Ltd), which included a gas-generating kit to maintain anaerobic conditions.

Within 2 hours of production, each faecal sample was diluted $(1: 10 \mathrm{w} / \mathrm{v})$ with phosphate-buffered saline $(0.1 \mathrm{M} ; \mathrm{pH} 7.2)$ and homogenised in a stomacher for $2 \mathrm{~min}$ at normal speed. The obtained faecal slurries were inoculated in the batch culture vessels obtaining a final solution of $10 \%(v / v)$ faecal slurry.

\subsection{Batch-culture fermentation}

Batch-culture fermentation was conducted to mimic physico-chemical conditions in the distal region of the human colon. Batch-culture fermentation vessels were sterilised and filled with $45 \mathrm{~mL}$ (in control trials and with $\mathrm{GO}$ and MGO standard solution; see 
section 2.5 for details) or $9 \mathrm{~mL}$ (in trials with 3-DG standard solution; see section 2.5 for details), of freshly steamed sterile basal nutrient medium containing peptone water (2 $\mathrm{g} / \mathrm{L})$, yeast extract $(2 \mathrm{~g} / \mathrm{L}), \mathrm{NaCl}(0.1 \mathrm{~g} / \mathrm{L}), \mathrm{K}_{2} \mathrm{HPO}_{4}(0.04 \mathrm{~g} / \mathrm{L}), \mathrm{KH}_{2} \mathrm{PO}_{4}(0.04 \mathrm{~g} / \mathrm{L}), \mathrm{NaHCO}_{3}$ (2 g/L), $\mathrm{MgSO}_{4} 7 \mathrm{H}_{2} \mathrm{O}(0.01 \mathrm{~g} / \mathrm{L}), \mathrm{CaCl}_{2} 6 \mathrm{H}_{2} \mathrm{O}(0.01 \mathrm{~g} / \mathrm{L})$, Tween-80 (2 mL/L), haemin (50 $\mathrm{mg} / \mathrm{L})$, vitamin $\mathrm{K} 1,(10 \mu \mathrm{L} / \mathrm{L})$, L-cysteine $(0.5 \mathrm{~g} / \mathrm{L})$, bile salts $(0.5 \mathrm{~g} / \mathrm{L})$, anaerobic indicator resazurin (1 mg/L) and distilled water. Media was gassed with a flow of $\mathrm{O}_{2}$-free $\mathrm{N}_{2}$ gas (15 $\mathrm{mL} / \mathrm{min}$ ) for a minimum of $12 \mathrm{~h}$ to achieve an anaerobic environment. The basal medium was maintained at $37^{\circ} \mathrm{C}$ using a circulating water bath and the $\mathrm{pH}$ was adjusted to $\mathrm{pH} 6.8$ and maintained between $\mathrm{pH} 6.7$ and 6.9 using an Electrolab $\mathrm{pH}$ controller with feeds of $0.5 \mathrm{M} \mathrm{HCl}$ and $0.5 \mathrm{M} \mathrm{NaOH}$, as appropriate. Different vessels were inoculated with faecal slurries ( $5 \mathrm{~mL}$ for control, $\mathrm{GO}$ and $\mathrm{MGO}$ and $1 \mathrm{~mL}$ for 3-DG, respectively) resulting from each donor.

Samples were collected at three-time points 0.1 (10 $\mathrm{min}), 8$ and $24 \mathrm{~h}$, for fluorescent in situ hybridization (FISH) and short-chain fatty acid analysis, and at fourtime points 0.1 (10 $\mathrm{min}), 4,8$ and $24 \mathrm{~h}$, for DCs HPLC analysis.

\subsection{Inoculation of the substrate in batch culture fermentation}

The starting concentrations of DCs used in batch culture fermentation were selected by considering the effect induced by SGD on each compound, to reflect the lowest $(L)$ and the highest $(H)$ levels of DCs intake with food items (Degen et al., 2012; Hellwig et al., 2018). The concentration of DCs inoculated in batch-culture vessels (1 mL, one per treatment) containing faecal slurry were the following:

3-DG: L-3DG, $54.6 \mathrm{mg} / \mathrm{kg} ; \mathrm{H}-3 D G, 127.3 \mathrm{mg} / \mathrm{kg}$

GO: L-GO, 4.7 mg/kg; H-GO, 23.5 mg/kg

MGO: L-MGO, 6.0 mg/kg; H-MGO, 219.6 mg/kg. 


\section{Journal Pre-proofs}

Fermentations without DCs were conducted as a control. Moreover, to study the stability of DCs during the batch-culture conditions, vessels containing basal medium and each DCs (one per treatment) without faecal slurry were subjected to the fermentation conditions.

\subsection{Extraction and HPLC analysis of 1,2-dicarbonyl compounds}

An aliquot of batch culture sample was centrifuged at $11,620 \mathrm{~g}$ for $20 \mathrm{~min}$ and the supernatant was filtered through $0.45 \mu \mathrm{m}$ filter (Albet). An aliquot (1 $\mathrm{mL})$ of the filtered supernatant was derivatised with a $0.2 \%$ of o-phenylenediamine (OPD) solution in water (Weigel, Opitz, Henle, 2004; Arena et al., 2011b). After 12 hours the derivatised mixture was analysed to measure the corresponding quinoxalines formed from DCs according to Brighina et al., (2020). The derivatised samples were injected into an HPLC series 1200 from Agilent (Waldbronn, Germany) with a DAD (G1315B DAD) and autosampler (G1329A).

The HPLC column used was a Phenomenex Kinetex, (75 mm $2.6 \mu$ C18 100Å) with a prefilter: KrudKatcher Ultra HPLC In-Line Filter (0.5u Depth Filter x 0.004in ID) (Phenomenex, Cheshire, UK) The HPLC conditions were: eluent A was $0.1 \%(\mathrm{v} / \mathrm{v})$ acetic acid in water and eluent B was methanol; flow rate, $0.7 \mathrm{~mL} / \mathrm{min}$; injection volume, $20 \mu \mathrm{L}$. The gradient program, where $t$ is expressed as minutes, was: $t 085 \% A$ and $15 \% B$; $t 10$ $65 \% \mathrm{~A}$ and $35 \% \mathrm{~B} ; t 1535 \% \mathrm{~A}$ and $65 \% \mathrm{~B} ; \mathrm{t} 25100 \% \mathrm{~B} ; \mathrm{t} 30 \mathrm{85} \% \mathrm{~A}$ and $15 \% \mathrm{~B}$. The detector wavelength was set to $312 \mathrm{~nm}$.

All compounds were identified by comparing retention times and UV spectra with those of standards and by spiking each sample with standards. Quantification of each compound was performed using external calibration curves.

\subsection{Bacterial enumeration}


To assess bacterial enumeration and the changes in the bacterial population, fluorescent in situ hybridisation (FISH) was used (Grimaldi et al., 2017).

$750 \mu \mathrm{L}$ of batch culture samples were centrifuged at $11,620 \mathrm{~g}$ for $5 \mathrm{~min}$, the resulting pellet was fixed for a minimum of $4 \mathrm{~h}$ at $4^{\circ} \mathrm{C}$ with $375 \mu \mathrm{L}$ of PBS and $1125 \mu \mathrm{L}$ cold $4 \%$ (v/v) paraformaldehyde solution (PFA). Fixed samples were centrifuged at 11,620 $g$ for 5 min and washed twice with PBS $(0 \cdot 1 \mathrm{M} ; \mathrm{pH}$ 7). Then, the remaining pellets were suspended in $300 \mu \mathrm{L}$ of PBS (99\%)-ethanol mixture $(1: 1, \mathrm{v} / \mathrm{v})$ and stored at $-20^{\circ} \mathrm{C}$ for at least $1 \mathrm{~h}$ before FISH analysis.

The FISH analysis was carried out with the following two steps:

1. Permeabilisation of the bacterial cell wall: $75 \mu \mathrm{L}$ of bacterial cell suspension was added to $500 \mu \mathrm{L}$ of PBS and then centrifuged at $11,620 \mathrm{~g}$ for $5 \mathrm{~min}$. The remaining pellet was added to TE-FISH containing lysozyme $(1 \mathrm{mg} / \mathrm{mL})$ and incubated in the dark for $10 \mathrm{~min}$ at room temperature. Then the sample was centrifuged at 11,620 $g$ for $5 \mathrm{~min}$, the pellet washed with $500 \mu \mathrm{L}$ of PBS and centrifuged at $11,620 \mathrm{~g}$ for 5 min.

2. In situ hybridisation: the pellet was suspended in $150 \mu \mathrm{L}$ of hybridisation buffer containing $\mathrm{NaCl}(5 \mathrm{M})$, Tris/HCl $(\mathrm{pH} 8.0 ; 1 \mathrm{M})$, formamide, double-distilled water, sodium dodecyl sulphate (10\%) and centrifuged at $11,620 \mathrm{~g}$ for $5 \mathrm{~min}$. After this, the pellet was suspended into $1 \mathrm{~mL}$ of hybridisation buffer. The hybridisation mixture $(50 \mu \mathrm{l})$ was added into Eppendorf with $4 \mu \mathrm{L}(50 \mathrm{ng} / \mathrm{mL})$ of the appropriate probe and incubated overnight at $35^{\circ} \mathrm{C}$. After the incubation period, the sample was centrifuged at $11,620 \mathrm{~g}$ for $5 \mathrm{~min}$ and the pellet was washed with $200 \mu \mathrm{L}$ of wash buffer solution containing $\mathrm{NaCl}(5 \mathrm{M})$, Tris/HCl $(\mathrm{pH} 8.0 ; 1 \mathrm{M})$, EDTA (pH 8.0; $0.5 \mathrm{M})$, double-distilled water and sodium dodecyl sulphate $(0.01 \%)$. The sample was incubated for $20 \mathrm{~min}$ at $37^{\circ} \mathrm{C}$ in a heating block. After the incubation period, the sample was centrifuged at 11,620 $\mathrm{g}$ for $5 \mathrm{~min}$ and the pellet was suspended 


\section{Journal Pre-proofs}

with $300 \mu \mathrm{L}$ of PBS and placed in the fridge at $4^{\circ} \mathrm{C}$ covered with aluminium foil (to protect samples from the light) until measurements on the cytometer (Accuri C6, BD Bioscience, UK).

The FISH oligonucleotides probes, hybridisation conditions and bacterial groups studied for enumeration are listened in Table 1.

\subsection{Short-Chain Fatty Acid analysis (SCFA)}

SCFA analysis was conducted using an acidification method adapted from Zhao et al. (2006). An aliquot of batch culture sample was centrifuged at 11,620 $\mathrm{g}$ for $20 \mathrm{~min}$, and the supernatant was filtered through $0.20 \mu \mathrm{m}$ filter (Albet). Calibration curves were prepared for acetic acid, propionic acid, isobutyric acid, butyric acid and valeric acid with a concentration between $0.5 \mathrm{mM}$ and $50 \mathrm{mM}$. An aliquot $(50 \mu \mathrm{L})$ of the filtered supernatant was mixed with $130 \mu \mathrm{L}$ of $\mathrm{H}_{2} \mathrm{SO}_{4}$ solution $\left(20 \mu \mathrm{L}\right.$ of $\mathrm{H}_{2} \mathrm{SO}_{4} / 100 \mathrm{~mL}$ water) and $45 \mu \mathrm{L}$ of 2ethyl butyric acid as internal standard solution. Following this $1 \mu \mathrm{L}$ of each sample was injected onto the column. The CG was a 5890 SERIES II Gas Chromatograph (Hewlett Packard, UK) with FFAP, capillary fused silica packed column $25 \mathrm{~m}$ by $0.32 \mathrm{~mm}$; film thickness, $0.25 \mu \mathrm{m}$ (Macherey- Nagel, Düren, Germany). Calibration curves were constructed and internal response factors calculated and used to determine the concentration of metabolites within the samples.

\subsection{Statistics}

All data obtained were subjected to analysis of variance (ANOVA). Differences between sample means were considered significant at $p \leq 0.05$. All statistical analyses were performed by using the Statistical package software IBM SPSS ${ }^{\circledR}$ Statistics version 25. 


\section{Results}

\subsection{Simulated Gastrointestinal Digestion (SGD)}

The SGD mimics the early processes of human digestion, taking into account digestive enzymes, $\mathrm{pH}$, time, among other factors. It has been used to assess the fraction of DCs passing to the next stages.

Although 3-DG is a highly reactive compound, SGD led to a concentration loss of 11.3 $\pm 1.3 \%$, indicating high stability of 3 -DG to digestion conditions. An effect of the SGD on both GO and MGO levels was also observed, with a concentration loss of $24.3 \% \pm 9.5$ and $24.3 \% \pm 13.3$, respectively. A study (Hamzalioğlu \& Gökmen, 2016), aimed to investigate the gastro-duodenal digestion of biscuits in vitro, reported an average decrease in 3-DG levels of $16-40 \%$, lower than MGO loss (29-68\%).

Our results suggest that in this model system, the majority of the DCs pass into the colon, where they could react with other substances and/or microorganisms. This, however, does not include the food matrix effects and the possible interactions with other food components.

The concentration loss induced by SGD was used to calculate the amounts of DCs to be inoculated in the batch culture to simulate both the lowest and highest levels of DCs dietary intake (Degen et al., 2012; Hellwig et al., 2018).

\subsection{Metabolism of 1,2-dicarbonyl compounds}

It is well known that DCs easily react with amino residues in proteins (cysteine, arginine, lysine) as well as could be trapped by aminoguanidine, creatin compounds delaying the AGEs formation, thus preventing the late consequences of diabetes (Thornalley, YurekGeorge \& Argirov, 2000; Löbner, Degen \& Henle, 2015; Hamzalioğlu \& Gokmen, 2016). The basal nutrient medium used for the batch culture fermentation contains peptone and 
L-cysteine that could interact with 1,2 dicarbonyl compounds during fermentation conditions acting as a competitor to the faecal microorganisms (Brighina et al., 2020).

To exclude any interference by the assay system, control fermentations with the faecal slurry but without DCs and with DCs but without the faecal slurry were carried out. This was to highlight: firstly the possible formation of DCs and secondly the stability of DCs in the fermentation conditions $\left(37^{\circ} \mathrm{C}, \mathrm{pH} 6.7-6.9\right)$. In all control samples, no $\mathrm{DC}$ was detected up to $24 \mathrm{~h}$, suggesting that the fermentation conditions do not favour their formation (data not shown). To evaluate the metabolism of DCs by human faecal microbiota, samples collected up to $24 \mathrm{~h}$ were analysed to quantify the residual amount of DCs.

Table 2 shows the changes in the residual levels of each DC during batch culture fermentations, with and without the presence of the faecal slurry.

When 3-DG at the lowest concentration (L-3DG) was incubated without faecal slurry, a statistically significant decrease in the concentration was observed and at $24 \mathrm{~h}$ the residual level was about $68 \%$. In the system with the highest concentration of 3-DG $(\mathrm{H}-$ 3DG), the levels remained almost constant and no significant differences were highlighted up to $24 \mathrm{~h}$ (Table 2 ).

The addition of faecal slurries bring to statistically significant decrease of the 3-DG levels, both at the lowest and highest levels. In the batch culture with faecal slurry, 3-DG was rapidly metabolised with a first-order reduction, both at the lowest and highest levels. At the first sample timepoint $(0.1,10 \mathrm{~min}$ ), the residual concentrations were 64 and $89 \%$ (for L-3DG and H-3DG, respectively). The results were different with the microbial community from donor 2; although at the end the 3-DG residual levels were comparable, 3-DG concentration was lost more slowly than with the other two donor's samples (Table 2). Moreover, except for the microbiota of donor 2, it seemed that the system, independently of the starting 3-DG concentration, used about $20 \mathrm{mg} / \mathrm{kg}$ after 0.1 hours and $50-85 \mathrm{mg} / \mathrm{kg}$ 
after 8 hours of incubation. After $24 \mathrm{~h}$, the residual level of 3-DG was about 0.5 and $2.0 \%$ in L-3DG and H-DG systems respectively.

The GO showed a decreasing trend of its level both in the system without or with faecal slurry (Table 2). There was significant difference between the two systems at incubation time $24 \mathrm{~h}$ in L-GO and during the first two sampling in the H-GO. The system with GO (no faecal slurry) showed a significant decrease at $24 \mathrm{~h}$ at both concentrations. In the L-GO system, the residual level reduced drastically after $4 \mathrm{~h}(58.8 \%)$ and successively degraded until about $80 \%$ at the end of treatment (Table 2). In $\mathrm{H}-\mathrm{GO}$ system, about $50 \%$ of the initial concentration was lost after $10 \mathrm{~min}$ and after $24 \mathrm{~h}$ the residual level was about $6 \%$. These results were in agreement with those reported on the interaction of the nutrient medium with GO (Brighina et al., 2020). The introduction of faecal microbiota did not lead to a further decrease in the GO residual level with the exception of L-GO system at $24 \mathrm{~h}$, whilst, the presence of faecal microbiota seemed to stabilise the $\mathrm{GO}$ at least until $4 \mathrm{~h}$ in H-GO system.

Great variation of residual levels of MGO was also observed, especially at the lowest concentration, both in the control and in the added faecal systems (Table 2). When MGO was added to system and batch culture no significant decrease was observed during the early minutes $(0.1,10 \mathrm{~min})$. After $4 \mathrm{~h}$ of incubation without faecal microbiota, the residual level of MGO was greatly reduced in L-MGO systems (9.9\%) and in subsequent samplings, MGO was completely lost. In the H-MGO system, an extensive but partial reduction occurred during incubation and at $24 \mathrm{~h}$ a residual level of about $36 \%$ was found (Table 2).

The initial concentration seemed to play a key role: in L-MGO, the faecal batch cultures had a protective effect on MGO and after 4 and $8 \mathrm{~h}$ the residual levels were about 46 and $22 \%$, respectively. At both sampling times, the residual levels were significantly higher than those determined in the systems without faecal microbiota. At $24 \mathrm{~h}$, MGO was 
completely lost in L-MGO. In the H-MGO a progressive fermentation was highlighted and, after $24 \mathrm{~h}$ of incubation, the residual level of MGO was about $14 \%$, significantly lower than those determined in the systems without faecal microorganisms (Table 2). It was reported that the reactions between MGO and tryptone soy broth medium (TSB) are kinetically favoured with respect to the reaction between microorganisms and MGO (Brighina et al., 2020).

\subsection{Changes in bacterial groups during in vitro batch culture fermentation}

FISH analysis, as proposed by other authors (Hidalgo et al., 2012; Alqurashi, Alarifi, Walton, Costabile, Rowland \& Commane 2017; Grimaldi et al., 2017), was used to evaluate the changes in bacterial, levels and populations, induced by the three dicarbonyls on the faecal microbiota. Fermentation with samples from the three faecal donors exhibited marked differences in microbial compositions. As observed in this study, the donor was one of the factors that influenced the degradation of DCs during batch culture fermentation. Considering the great variability among individuals, it was not deemed appropriate to average the results of the three individuals and therefore the results were reported for each donor (Figures 1,2 and 3), as suggested by Helou, Anton, Niquet-Léridon, Spatz, Tessier, and Gadonna-Widehem, (2015).

Fermentation in the presence of 3-DG altered both the distribution and the level of microbial groups, as compared to the negative control (Fig. 1). Even at the lowest concentration $(54.6 \mathrm{mg} / \mathrm{kg})$, there was an effective antibacterial effect, mainly against Bifidobacterium spp. (BIF), Lactobacillus/Enterococcus spp. (LAB) and Bacteroides spp. (BAC). 3-DG also influenced the presence of Clostridium coccoides-Eubacterium rectale group (EREC), Roseburia spp. (RREC), Faecalibacterium prausnitzii group (FPRAU), Desulfovibrionales (excluding Lawsonia) and many Desulfuromonales (DSV) and C. histolyticum group (CHIS). The microbial reduction, relative to negative control vessels, 
was even greater in the presence of the highest 3-DG concentration $(217.7 \mathrm{mg} / \mathrm{kg})$, specifically following fermentation of microbiota from donors 1 and 3 , with over $5 \log _{10}$ fewer bacteria as compared to the negative control for BAC, DSV and between 3-5 $\log _{10}$ fewer bacterial numbers per $\mathrm{mL}$ for LAB and CHIS (Fig 1).

$\mathrm{GO}$, at the lowest concentration $(4.7 \mathrm{mg} / \mathrm{kg})$, had a negligible effect on microorganisms (Fig. 2). At the highest concentration, $25.5 \mathrm{mg} / \mathrm{kg}$, there was a reduction with respect to the negative control vessels, of more than $1 \log _{10}$ bacterial numbers per $\mathrm{mL}$. As such it was observed that at these concentrations gut microorganisms tolerate $\mathrm{GO}$. The bacteria of donor 3 were less sensitive to GO (Fig. 2).

Fermentation of MGO, at the lowest concentration $(6 \mathrm{mg} / \mathrm{kg})$, led to a $1 \mathrm{Log}_{10}$ reduction of bacterial numbers per $\mathrm{mL}$ for $\mathrm{LAB}$ and $\mathrm{DSV}$ for donors 1 and 2 , compared to the negative control (Fig. 3). At the highest concentration $(220 \mathrm{mg} / \mathrm{kg})$ bacteria of donor 3 were re sensitive and there was a reduction of 4-6 $\log _{10}$ bacterial numbers per $\mathrm{mL}$ of LAB, BAC and FPRAU and $2 \log _{10}$ for others EREC, RREC, Clostridium cluster IX (PRO). Whilst the bacteria of donors 1 and 2 were less sensitive to the highest level of MGO resulting in 1-3 $\log _{10}$ lower bacterial numbers per $\mathrm{mL}$ for $\mathrm{LAB}, \mathrm{BAC}, \mathrm{CHIS}, \mathrm{PRO}$ and DSV as compared to the negative control (Fig. 3).

When the data was averaged, even with the great variation observed after 24 hours fermentation there were significantly fewer lactobacilli upon fermentation of 3-DG and MGO ( $p=0.01$ and 0.01 , respectively). Furthermore 3-DG also resulted in lower levels of FPRAU, PRO and DSV ( $p=0.03,0.01$ and 0.03 , respectively).

\subsection{Short Chain Fatty Acids (SCFA)}

SCFA are the non-gaseous end-products of fermentation reactions formed during digestion (Cummings, 1981). They have been associated both with the type of digested carbohydrates and their concentrations. SCFA can underline an adaptive immune 
microbiota to promote colon homeostasis and health (Morrison \& Preston, 2016). Table S1 reports data of SCFA, for each donor and the dicarbonyl added ones. Moreover, the net effect of each dicarbonyl is reported as the difference between the SCFA concentration in the dicarbonyl and the corresponding control sample.

The level of SCFA in the three donors samples, used as a control, confirms that in vitro digestion is specific for each donor. The level of all SCFA, but caproic, increased during the 24 hours of fermentation; this was observed for all donors for acetic and propionic acids. Butyric, iso-butyric and valeric acids increased only in donors 1 and 3 . The fermentation with bacteria from donor 1 led to the highest levels of all SCFA $\cong 7.7 \mathrm{mM}$ for acetic, $\cong 7 \mathrm{mM}$ for butyric, $\cong 4$ for valeric and $\cong 2 \mathrm{mM}$ for propionic and iso-butyrric acids) while donor 2 showed the lowest levels $(\cong 2.5 \mathrm{mM}$ for acetic and $\cong 1 \mathrm{mM}$ for propionic acid).

The presence of dicarbonyl compounds modified the levels of SCFA. The addition of 3DG to the D1 system resulted in less SCFA as compared to the control, particularly after $24 \mathrm{~h}$ at the highest 3-DG concentration. In practice, after $24 \mathrm{~h}$ there were lower levels of SCFA when compared to the control. Also in the other two donors systems, there were less SCFA (Table S1). Therefore, the microbial community was disrupted by the treatment and as such the community was less able to produce the SCFA / BCFA endproducts.

The addition of GO to the donor 1 system, at the highest concentration, adversely affected the gut microbiota hence the SCFA levels were lower. On the other hand, within the donor 2 system, higher levels of SCFA were observed as compared to the corresponding control sample; this was particularly evident for acetic and butyric acids at the lowest GO level (Table S1). The GO in the donor 3 system led to the highest fermentation activity in the early stage $(0.1 \mathrm{~h})$ then declining to no net production after 24 hours. 


\section{Journal Pre-proofs}

The addition of MGO, almost in all of the three donor systems, slowed down SCFA production even at the lowest concentration. At the highest one, MGO, analogously to 3DG, was very effective in preventing the fermentation routes to SCFA production throughout the fermentation (Table S1).

\section{DISCUSSION}

Results of SGD have indicated that the majority of the ingested DCs, about $75 \%$ of GO and MGO or $90 \%$ of $3-D G$, are likely to pass intact through the first phase of digestion to the enter the large intestine. Although with some differences within the large intestine the DCs rapidly decrease. For example, the 3-DG was stable in control samples, with the absence of faecal bacteria, but degraded very quickly, with first-order kinetics, under anaerobic digestion conditions (faecal slurry). Both GO and MGO were unstable under the studied conditions in control and the faecal fermenters, with differences due to concentration or to the presence of the faecal slurry. This means that substantial parts of these molecules could be degraded already within the media, without the inclusion of faecal bacteria. Further studies would be necessary to highlight the ratios of GO/MGO reacting with each part of the system. Other in vitro studies (Daglia, Ferrari, Collina \& Curti, 2013; Degen, Vogel, Richter, Hellwig \& Henle, 2013) have shown the reaction of MGO with digestive enzymes. Our results are similar to those reported for high MGO Manuka honey (concentration loss 19-24\%; Daglia et al., 2013), but much lower than values reported in the two cited studies for standard MGO solutions (concentration loss > 70\%; Daglia et al., 2013) and Manuka honey (Degen et al., 2013).

The literature largely reports the high level of dietary intake of AGEs (Advanced Glycation End-products) (Henle, 2003, 2005; Delgado-Andrade, 2016), and the deleterious health effects (Singh, Barden, Mori \& Beilin, 2001; Shimizu et al., 2013). If the degradation routes of DCs during digestion do not lead to the formation of AGEs, this could result in them 
passing into the colon, to be promptly degraded while exerting their antimicrobial capacity.

On the other hand, being DCs the precursors of AGEs, if their degradation routes lead to AGEs, this could be a concern. Further mechanistic studies are needed. Also, the data of this study demonstrated that 3-DG can play a crucial role under metabolic digestion conditions, because of its high reactivity and large spread in cooked foods (Degen et al., 2012) and honey (Mavric et al., 2008; Arena et al., 2011a, b).

The antimicrobial properties of $\alpha$-dicarbonyl compounds have been investigated for a long time (Jay et al., 1983), along with investigations on Manuka honey properties (Adams et al., 2008; Mavric et al., 2008; Blair et al., 2009). All these previous studies and a very recent one (Brighina et al., 2020) agree that 3-DG do not have, except at very high concentration, any antimicrobial activity. On the contrary, the FISH analysis reported in the present study has shown that 3-DG is the most powerful of the three studied DCs in reducing microbial levels under anaerobic conditions. This could help to explain the ability of Manuka honey at modifying both positive and negative gut bacteria, with MGO under the required limit to inhibit bacterial growth (Rosendale et al. 2008).

The ability of 3-DG in reducing bacterial level depended on the starting community provided by the donor, but it leads to a reduction of bacterial populations. 3-DG reduced the population of beneficial bacteria, for instance, BIF and $L A B$, and of BAC, EREC, and also DSV. The ability of 3-DG to slow down or to arrest the fermentation reactions is also confirmed by the SCFA levels. While SCFA level increased in the control fermentations during the 24 hours of fermentation, in the presence of 3-DG SCFAs levels were lower. In particular, it seemed that acetic and butyric acids, related to BIF, BAC (Collins \& Gibson, 1999), EREC and FPRAU (Kim, Park \& Kim, 2014) respectively, disappeared. Furthermore, when looking at the data as a whole 3-DG and MGO seemed effective at reducing numbers of lactobacilli, genera often associated with positive effects. 


\section{Journal Pre-proofs}

With regards to $\mathrm{GO}$ and $\mathrm{MGO}$, under the studied conditions, almost $75 \%$ of the two molecules can reach the colon. But, due to their high reactivity or the low starting initial concentration, the hypothesis of interferences by the assay system seemed to be confirmed (Brighina et al., 2020). Both molecules reacted very quickly with compounds present in the control sample (e.g., nutrient medium containing peptone, cysteine, etc.; see section 2.2.), making it difficult or impossible to distinguish between the fraction consumed by the measurement system (control) and the fraction consumed during the digestion processes (in the presence of faecal slurry). As a consequence, the digestion results concerning GO and MGO could be underestimated.

Results of the present study evidenced that all the dicarbonyls, tested at levels similar to food intake, were able to reduce the bacterial groups and thus exert a negative effect in the intestinal bacterial population, showing a direct effect on digestion processes. In particular for 3-DG when used at the highest concentration $(127.7 \mathrm{mg} / \mathrm{kg})$, reduced the population of the microbial groups tested and SCFA levels, whilst at the lowest concentration (54.5 mg/kg), 3-DG exerted an effective antibacterial effect against the positive bacteria BIF and LAB. To the best of our knowledge the antibacterial activity of 3-DG has not previously been demonstrated. The daily intake of this compound can easily reach the levels tested with the common diet, since the daily food basket, containing fruit juices, honey, biscuits, bread and jam, can provide a 3-DG daily intake ranging from about $36 \mathrm{mg}$ up to $270 \mathrm{mg}$ (Degen et al., 2012). Moreover, the ingested amounts of 3-DG exceed those of the other 1,2-dicarbonyl compounds by about 10-fold (Degen et al., 2012).

This is of particular interest because ready-to-consume hyper-palatable (ultra-processed) foods, that are characteristic of the Western diet and could therefore lead to a noticeable reduction of bacteria important to the microbiome. Many commonly consumed ultraprocessed foods, such as breakfast cereals, bread, cookies and carbohydrate-rich 
snacks, are an important source of dicarbonyl compounds. Due to the heterogeneity and the multitude of reactive compounds that arise from the heat treatment of processed foods and their apparent contradictory effect, daily intake of these foods should be focused as a factor that could influence microbiota diversity and function. Also, heat-treatment of the food could further impact of the antimicrobial potential of these foods and as such warrants further investigation.

This paper, for the first time, used realistic levels of DCs for in vitro gastrointestinal and fermentative digestion using isolated compounds. In successive research real foods should be studied to consider the effects of the food matrix and the possible interaction between different food components (nutrients and non-nutrients) on the antimicrobial potential of these components within the gut. 


\section{References}

Adams, C. J., Boult, C. H., Deadman, B. J., Farr, J. M., Grainger, M. N. C., Manley-Harris, M., \& Snow, M. J. (2008). Isolation by HPLC and characterisation of the bioactive fraction of New Zealand manuka (Leptospermum scoparium) honey. Carbohydrate Research, 343, 651-659.

Alqurashi, R. M., Alarifi, S. N., Walton, G. E., Costabile, A. F., Rowland, I. R., \& Commane, D. M. (2017). In vitro approaches to assess the effects of açai (Euterpe oleracea) digestion on polyphenol availability and the subsequent impact on the faecal microbiota. Food Chemistry, 234, 190-198.

Arena, E., Ballistreri, G., \& Fallico, B. (2011). Kinetics of 3-deoxy-D-erythro-hexos-2ulose in unifloral honeys. Journal of Food Science, 76, C1044-C1049.

Arena, E., Ballistreri, G., Tomaselli, F., \& Fallico, B. (2011). Survey of 1, 2-dicarbonyl compounds in commercial honey of different floral origin. Journal of Food Science, 76, C1203-C1210.

Blair, S. E., Cokcetin, N. N., Harry, E. J., \& Carter, D. A. (2009). The unusual antibacterial activity of medical-grade Leptospermum honey: Antibacterial spectrum, resistance and transcriptome analysis. European Journal of Clinical Microbiology \& Infectious Diseases, 28, 1199-1208.

Brighina, S., Restuccia, C., Arena, E., Palmeri, P., \& Fallico, B. (2020). Antibacterial activity of 1,2-dicarbonyl compounds and the influence of the in vitro assay system. Food Chemistry, 311, 125905. https://doi.org/10.1016/j.foodchem.2019.125905.

Collins, M. D., \& Gibson, G. R. (1999). Probiotics, prebiotics, and synbiotics: Approaches for modulating the microbial ecology of the gut. The American journal of clinical nutrition, 69(5), 1052s-1057s.

Cummings, J. H. (1981). Short chain fatty acids in the human colon. Gut, 22(9), 763. 
Daglia, M., Ferrari, D., Collina, S., \& Curti, C. (2013). Influence of in Vitro Simulated

Gastroduodenal Digestion on Methylglyoxal Concentration of Manuka (Lectospermum scoparium) Honey. Journal of Agricultural and Food Chemistry, 61, 2140-2145. doi: 10.1021/jf304299d

Degen, J., Hellwig, M., \& Henle, T. (2012). 1,2-Dicarbonyl Compounds in Commonly Consumed Foods. Journal of Agricultural and Food Chemistry, 60, 7071-7079. doi: $10.1021 / \mathrm{jf} 301306 \mathrm{~g}$

Degen, J., Vogel, M., Richter, D., Hellwig, M., \& Henle, T. (2013). Metabolic Transit of Dietary Methylglyoxal. Journal of Agricultural and Food Chemistry, 61, 1025310260. doi: $10.1021 / \mathrm{jf} 304946 p$

Del Rio, D., Rodriguez-Mateos, A., Spencer, J. P. E., Tognolini, M., Borges, G., \& Crozier, A. (2013). Dietary (poly) phenolics in human health: structures, bioavailability, and evidence of protective effects against chronic diseases. Antioxidants \& Redox Signaling, 18, 1818-1892. doi:10.1089/ars.2012.4581

Delgado-Andrade, C. (2016). Carboxymethyl-lysine: thirty years of investigation in the field of AGE formation. Food \& function, 7(1), 46-57.

Dicksved J (2008) Exploring the human intestinal microbiome in health and disease. Dissertation, Thesis Swedish University of Agricultural Sciences, Acta Universitatis $\begin{array}{lll}\text { Agriculturae } & \text { Sueciae } & \text { 2008:30. }\end{array}$ http://pub.epsilon.slu.se/1760/1/Dicksved_Thesis_Kappan.pdf Accessed 24 Apr 2014.

Duda-Chodak, A., Tarko, T., Satora, P., \& Sroka, P. (2015). Interaction of dietary compounds, especially polyphenols, with the intestinal microbiota: a review. European journal of nutrition, 54(3), 325-341. doi.org/10.1007/s00394-015-0852-y. Grimaldi, R., Cela, D., Swann, J. R., Vulevic, J., Gibson, G. R., Tzortzis, G., \& Costabile, A. (2017).In vitro fermentation of B-GOS: impact on faecal bacterial populations and 
metabolic activity in autistic and non-autistic children. FEMS Microbiology Ecology, 93, fiw233. doi:10.1093/femsec/fiw233.

Hamzalıoğlu, A., \& Gökmen, V. (2016). Investigations on the reactions of $\alpha$-dicarbonyl compounds with amino acids and proteins during in vitro digestion of biscuits. Food and Function, 7, 2544-2550.

Hayashi, K., Fukushima, A., Hayashi-Nishino, M., \& Nishino, K. (2014). Effect of methylglyoxal on multidrug-resistant Pseudomonas aeruginosa. Frontiers in microbiology, 5, 180.

Hellwig, M., Gensberger-Reigl, S., Henle, T., \& Pischetsrieder, M. (2018). Food-derived 1,2-dicarbonyl compounds and their role in diseases. Seminars in Cancer Biology, 49, 1-8.

Helou, C., Anton, P. M., Niquet-Léridon, C., Spatz, M., Tessier, F. J., \& GadonnaWidehem, P. (2015). Faecal excretion of Maillard reaction products and the gut microbiota composition of rats fed with bread crust or bread crumb. Food \& Function, 8, 2722-2730.

Henle, T. (2003). AGEs in foods: do they play a role in uremia?. Kidney international, 63, S145-S147.

Henle, T. (2005). Protein-bound advanced glycation endproducts (AGEs) as bioactive amino acid derivatives in foods. Amino acids, 29(4), 313-322.

Hidalgo, M., Oruna-Concha, M. J., Kolida, S., Walton, G. E., Kallithraka, S., Spencer, J. P. E., Gibson, G. R. \& de Pascual-Teresa, S. (2012). Metabolism of Anthocyanins by Human Gut Microflora and Their Influence on Gut Bacterial Growth. Journal of Agricultural and Food Chemistry, 60, 3882-3890. doi: 10.1021/jf3002153.

Jay, J. M., Rivers, G. M., \& Boisvert, W. E. (1983). Antimicrobial properties of a-dicarbonyl and related compounds. Journal of food protection, 46(4), 325-329. 
Kim, C. H., Park, J., \& Kim, M. (2014). Gut microbiota-derived short-chain fatty acids, T cells, and inflammation. Immune network, 14(6), 277-288.

Löbner, J., Degen, J., \& Henle, T. (2015). Creatine Is a Scavenger for Methylglyoxal under Physiological Conditions via Formation of N-(4-Methyl-5-oxo-1-imidazolin-2-yl) sarcosine (MG-HCr). Journal of Agricultural and Food Chemistry, 63, 2249-2256. doi: 10.1021/jf505998z.

Mavric, E., Wittmann, S., Barth, G., \& Henle, T. (2008). Identification and quantification of methylglyoxal as the dominant antibacterial constituent of manuka (Leptospermum scoparium) honeys from New Zealand. Molecular Nutrition \& Food Research, 52, 483-489.

Mills D.J., Tuohy K.M., Booth J., Buck M., Crabbe M.J.C., Gibson G.R., Ames J.M. (2008). Dietary glycated protein modulates the colonic microbiota towards a more detrimental composition in ulcerative colitis patients and non-ulcerative colitis subjects. Journal of Applied Microbiology, 105, 706-714.

Morrison, D. J., Preston, T., (2016) Formation of short chain fatty acids by the gut microbiota and their impact on human metabolism, Gut Microbes, 7:3, 189-200, DOI:10.1080/19490976.2015.1134082.

Rosendale, D. I., Maddox, I. S., Miles, M. C., Rodier, M., Skinner, M., \& Sutherland, J. (2008). High-throughput microbial Bioassays to screen potential New Zealand functional food ingredients intended to manage the growth of probiotic and pathogenic gut bacteria. International Journal of Food Science \& Technology, 43, 2257-2267.

Rosendale, D., Butts, C. A., de Guzman, C. E., Maddox, I. S., Martell, S., Mclntyre, L., Skinner M.A., Dinnan H., Ansell, J. (2016). Consumption of antimicrobial manuka honey does not significantly perturb the microbiota in the hind gut of mice. PeerJ, 4 , e2787. 
Saarela, M., Lähteenmäki, L., Crittenden, R., Salminen, S., Mattila-Sandholm, T. (2002).

Gut bacteria and health foods-the European perspective. International Journal of Food Microbiology, 78, 99-117. doi.org/10.1016/S0168-1605(02)00235-0.

Sharma, C., Kaur, A., Thind, S. S., Singh, B., \& Raina, S. (2015). Advanced glycation End-products (AGEs): an emerging concern for processed food industries. Journal of food science and technology, 52(12), 7561-7576.

Shimizu, F., Sano, Y., Tominaga, O., Maeda, T., Abe, M. A., \& Kanda, T. (2013). Advanced glycation end-products disrupt the blood-brain barrier by stimulating the release of transforming growth factor- $\beta$ by pericytes and vascular endothelial growth factor and matrix metalloproteinase-2 by endothelial cells in vitro. Neurobiology of aging, 34(7), 1902-1912.

Singh, R., Barden, A., Mori, T., \& Beilin, L. (2001). Advanced glycation end-products: a review. Diabetologia, 44(2), 129-146.

Snelson, M., \& Coughlan, M. T. (2019). Dietary advanced glycation end products: digestion, metabolism and modulation of gut microbial ecology. Nutrients, 11(2), 215.

Thornalley, P. J., Yurek-George, A., \& Argirov, O. K. (2000). Kinetics and mechanism of the reaction of aminoguanidine with the alpha-oxoaldehydes glyoxal, methylglyoxal, and 3-deoxyglucosone under physiological conditions. Biochemical Pharmacology, $60,55-65$.

Weigel, K. U., Opitz, T., \& Henle, T. (2004). Studies on the occurrence and formation of 1, 2-dicarbonyls in honey. European Food Research and Technology, 218, 147-151.

Zhao, G., Nyman, M., Jönsson, J.A. (2006). Rapid determination of short-chain fatty acids in colonic contents and faeces of humans and rats by acidified water-extraction and direct-injection gas chromatography. Biomedical Chromatography, 20, 674-682. 
Zhu, B., Wang, X., \& Li, L. (2010). Human gut microbiome: the second genome of human body. Protein \& Cell, 1, 718-725. doi:10.1007/s13238-010-0093-z. 
Journal Pre-proofs

Table 1. FISH oligonucleotides probes used and bacterial groups studied.

\begin{tabular}{|c|c|c|c|c|}
\hline $\begin{array}{l}\text { Probe } \\
\text { name }\end{array}$ & Sequence (5' to $\left.3^{\prime}\right)$ & $\begin{array}{l}\text { Targed bacterial } \\
\text { group/species }\end{array}$ & $\begin{array}{l}\mathrm{T}_{\mathrm{H}} \\
\left({ }^{\circ} \mathrm{C}\right)\end{array}$ & Reference \\
\hline Non Eub & ACTCCTACGGGAGGCAGC & No bacteria & 35 & $\begin{array}{l}\text { Wallner et } \\
\text { al. (1993) }\end{array}$ \\
\hline Eub338 & GCTGCCTCCCGTAGGAGT & Total bacteria & 35 & $\begin{array}{l}\text { Daims et al. } \\
\text { (1999) }\end{array}$ \\
\hline Eub338II & GCAGCCACCCGTAGGTGT & Total bacteria & 35 & $\begin{array}{l}\text { Daims et al. } \\
\text { (1999) }\end{array}$ \\
\hline Eub338III & GCTGCCACCCGTAGGTGT & Total bacteria & 35 & $\begin{array}{l}\text { Daims et al. } \\
\text { (1999) }\end{array}$ \\
\hline Bif164 & CATCCGGCATTACCACCC & Bifidobacterium spp. & 35 & $\begin{array}{l}\text { Langen.dijk } \\
\text { et al. (1995) }\end{array}$ \\
\hline Lab158 & GGTATTAGCAYCTGTTTCCA & $\begin{array}{l}\text { Lactobacillus/Enterococcus } \\
\text { spp }\end{array}$ & 35 & $\begin{array}{l}\text { Harmsen et } \\
\text { al. (1999) }\end{array}$ \\
\hline Bac303 & CCAATGTGGGGGACCTT & Bacteroides spp & 35 & $\begin{array}{l}\text { Manz et al. } \\
(1996)\end{array}$ \\
\hline Erec482 & GCTTCTTAGTCARGTACCG & $\begin{array}{l}\text { Clostridium coccoides- } \\
\text { Eubacterium rectale group }\end{array}$ & 35 & $\begin{array}{l}\text { Franks et al. } \\
\text { (1998) }\end{array}$ \\
\hline Rrec584 & TCAGACTTGCCGYACCGC & Roseburia genus & 35 & $\begin{array}{l}\text { Walker et al. } \\
(2005)\end{array}$ \\
\hline Ato291 & GGTCGGTCTCTCAACCC & Atopobium spp & 35 & $\begin{array}{l}\text { Harmsen et } \\
\text { al. (2000) }\end{array}$ \\
\hline Prop853 & ATTGCGTTAACTCCGGCAC & Clostridium cluster IX. & 35 & $\begin{array}{l}\text { Walker et al. } \\
(2005)\end{array}$ \\
\hline Fprau655 & CGCCTACСTCTGCACTAC & $\begin{array}{l}\text { Faecalibacterium prausnitzii } \\
\text { group }\end{array}$ & 35 & $\begin{array}{l}\text { Devereux et } \\
\text { al. (1992) }\end{array}$ \\
\hline DSV687 & TACGGATTTCACTCCT & $\begin{array}{l}\text { Desulfovibrionales (excluding } \\
\text { Lawsonia) an.d many } \\
\text { Desulfuromonales }\end{array}$ & 35 & $\begin{array}{l}\text { Hold et al. } \\
(2003)\end{array}$ \\
\hline Chis150 & TTATGCGGTATTAATCTYCCTTT & C. histolyticum group & 35 & $\begin{array}{l}\text { Franks et al. } \\
\text { (1998) }\end{array}$ \\
\hline
\end{tabular}




\section{Journal Pre-proofs}

Table 2. Residual levels percentage (average value and for each donor) of 1,2 dicarbonyl compounds in a $\mathrm{pH}$-controlled anaerobic fermentation vessels in presence or absence of gut microflora.

\begin{tabular}{|c|c|c|c|c|c|}
\hline & & & Time (h) & & \\
\hline $\begin{array}{l}\text { Initial } \\
\text { level }\end{array}$ & Residual level \% & $0.1^{\mathrm{a}}$ & 4 & 8 & 24 \\
\hline \multirow{5}{*}{ 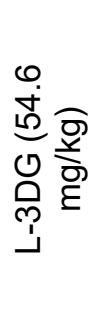 } & Without faecal slurry & $107.2 \pm 0.5 \mathrm{Aa}$ & 101.1 $\pm 0.6 \mathrm{Ab}$ & $80.3 \pm 0.3 \mathrm{Ac}$ & $67.6 \pm 0.7 \mathrm{Ad}$ \\
\hline & + faecal slurry & $64.3 \pm 23.3 \mathrm{Aa}$ & $54.8 \pm 13.1 \mathrm{Ba}$ & $17.3 \pm 11.5 \mathrm{Bb}$ & $0.53 \pm 0.9 \mathrm{Bc}$ \\
\hline & Donor1 & 57.3 & 56.6 & 30.1 & n.d \\
\hline & Donor2 & 90.3 & 66.8 & 13.7 & 1.6 \\
\hline & Donor3 & 45.2 & 40.8 & 7.9 & nd \\
\hline \multirow{5}{*}{ 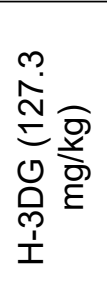 } & Without faecal slurry & $126.7 \pm 10.0 \mathrm{Aa}$ & 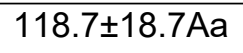 & $136.0 \pm 36.0 \mathrm{Aa}$ & $114.6 \pm 14.6 \mathrm{Aa}$ \\
\hline & + faecal slurry & $89.4 \pm 7.1 \mathrm{Ba}$ & $67.3 \pm 6.0 \mathrm{Bb}$ & $53.5 \pm 16.2 \mathrm{BC}$ & $2.03 \pm 2.1 \mathrm{Bd}$ \\
\hline & Donor1 & 83.9 & 59.4 & 68.8 & n.d \\
\hline & Donor2 & 98.8 & 71.3 & 59.0 & 1.4 \\
\hline & Donor3 & 85.4 & 71.4 & 32.7 & 4.7 \\
\hline \multirow{5}{*}{ 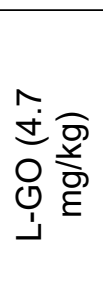 } & Without faecal slurry & $130.4 \pm 16.5 \mathrm{Aa}$ & $58.8 \pm 3.4 \mathrm{Ab}$ & $30.2 \pm 6.3 \mathrm{Ac}$ & $20.5 \pm 3.5 \mathrm{Ac}$ \\
\hline & + faecal slurry & $113.9 \pm 13.8 \mathrm{Aa}$ & $62.1 \pm 5.3 \mathrm{Ab}$ & $37.1 \pm 7.9 \mathrm{Ac}$ & $3.89 \pm 2.92 \mathrm{Bd}$ \\
\hline & Donor1 & 117.7 & 63.05 & 27.76 & 5.95 \\
\hline & Donor2 & 96.40 & 55.61 & 36.19 & 5.71 \\
\hline & Donor3 & 127.60 & 67.71 & 45.62 & 0.97 \\
\hline
\end{tabular}

\begin{tabular}{|c|c|c|c|c|c|}
\hline \multirow{5}{*}{ 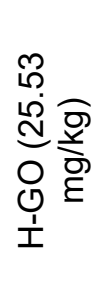 } & Without faecal slurry & $49.6 \pm 10.4 \mathrm{Ba}$ & $46.4 \pm 9.8 \mathrm{Ba}$ & $32.4 \pm 0.28 \mathrm{Ab}$ & $6.5 \pm 0.2 A c$ \\
\hline & + faecal slurry & $115.8 \pm 14.5 \mathrm{Aa}$ & $64.5 \pm 6.74 \mathrm{Ab}$ & $31.3 \pm 5.39 \mathrm{Ac}$ & $9.42 \pm 2.50 \mathrm{Ad}$ \\
\hline & Donor1 & 116.06 & 67.47 & 24.97 & 7.57 \\
\hline & Donor2 & 99.98 & 55.72 & 31.51 & 12.75 \\
\hline & Donor3 & 137.18 & 70.42 & 37.35 & 7.94 \\
\hline \multirow{5}{*}{ 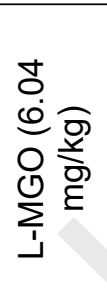 } & Without faecal slurry & $90.2 \pm 3.4 \mathrm{Aa}$ & $9.9 \pm 1.0 \mathrm{Ab}$ & $0.5 \pm 0.0 \mathrm{Bc}$ & n.d \\
\hline & + faecal slurry & $91.2 \pm 26.3 \mathrm{Aa}$ & $46.2 \pm 21.0 \mathrm{Ab}$ & $21.9 \pm 18.7 \mathrm{Ac}$ & n.d \\
\hline & Donor1 & 119.70 & 74.24 & 44.27 & n.d \\
\hline & Donor2 & 59.35 & 31.24 & 1.12 & n.d \\
\hline & Donor3 & 94.42 & 33.14 & 20.25 & n.d \\
\hline
\end{tabular}

\begin{tabular}{|c|c|c|c|c|c|}
\hline \multirow{5}{*}{ 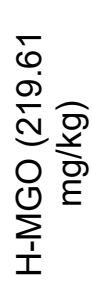 } & Without faecal slurry & $127.2 \pm 15.3 \mathrm{Aa}$ & $84.1 \pm 3.6 \mathrm{Ab}$ & $53.8 \pm 5.0 \mathrm{Ac}$ & $36.1 \pm 1.0 \mathrm{Ad}$ \\
\hline & + faecal slurry & $111.9 \pm 9.03 \mathrm{Aa}$ & $68.4 \pm 15.9 \mathrm{Ab}$ & $35.5 \pm 25.7 \mathrm{Ac}$ & $14.4 \pm 11.7 \mathrm{Bd}$ \\
\hline & Donor1 & 116.06 & 47.77 & 50.66 & 15.73 \\
\hline & Donor2 & 99.98 & 74.27 & 54.55 & 27.17 \\
\hline & Donor3 & 119.51 & 83.14 & 1.25 & 0.16 \\
\hline
\end{tabular}

a $0.1,10$ min. Data expressed as the mean \pm standard deviation. In each column, values followed by different capital letters within the same dicarbonyl compounds level and time and are significantly different according to Fisher's least significant difference test $(p \leq 0.05)$. In each row, values followed by different lowercase letters are significantly different according to Fisher's least significant difference test $(p \leq 0.05)$ 


\section{Figure Captions}

Fig. 1. Influence of low $(54.5 \mathrm{mg} / \mathrm{kg})$ and high $(127.7 \mathrm{mg} / \mathrm{kg})$ levels of 3-DG on the gut microbiota of different donors (D1, D2, D3) in a pH-controlled anaerobic fermentation vessels $(1 \%$ faecal slurry, $\mathrm{n}=1$ ) quantified using fluorescence in situ hybridisation. Samples were collected at time (T) 0.1 (10 min), 8, and 24 h. Bacterial name: TOTAL: Total bacteria; BIF: Bifidobacterium spp.; LAB: Lactobacillus/Enterococcus spp; BAC: Bacteroides spp; EREC: Clostridium coccoidesEubacterium rectale group; RREC: Roseburia genus; ATO: Atopobium spp; PRO: Clostridium cluster IX; FPRAU: Faecalibacterium prausnitzii group; DSV: Desulfovibrionales (excluding Lawsonia) and many Desulfuromonales; CHIS: C. histolyticum group. Changes in bacterial growth calculated by comparing the number of a specific bacterial group in the treatment with the number found in a control group, at the same time point.

Fig. 2. Influence of low $(4.07 \mathrm{mg} / \mathrm{kg})$ and high $(25.5 \mathrm{mg} / \mathrm{kg})$ levels $\mathrm{GO}$ on the gut microbiota of different donors (D1, D2, D3) in a pH-controlled anaerobic fermentation vessels ( $1 \%$ faecal slurry, $\mathrm{n}=1$ ) quantified using fluorescence in situ hybridisation. Samples were collected at time (T) 0.1 (10 min), 8, and 24 h. Bacterial name:TOTAL: Total bacteria; BIF: Bifidobacterium spp.; LAB: Lactobacillus/Enterococcus spp; BAC: Bacteroides spp; EREC: Clostridium coccoidesEubacterium rectale group; RREC: Roseburia genus; ATO: Atopobium spp; PRO: Clostridium cluster IX; FPRAU: Faecalibacterium prausnitzii group; DSV: Desulfovibrionales (excluding Lawsonia) and many Desulfuromonales; CHIS: C. histolyticum group. Changes in bacterial growth calculated by comparing the number of a specific bacterial group in the treatment with the number found in a control group, at the same time point.

Fig. 3. Influence of low $(6.04 \mathrm{mg} / \mathrm{kg})$ and high $(219.6 \mathrm{mg} / \mathrm{kg})$ levels of MGO on the gut microbiota of different donors (D1, D2, D3) in a pH-controlled anaerobic fermentation vessels $(1 \%$ faecal slurry, $\mathrm{n}=1$ ) quantified using fluorescence in situ hybridisation. Samples were collected at time (T) 0.1 (10 min), 8, and $24 \mathrm{~h}$. Bacterial name:TOTAL: Total bacteria; BIF: Bifidobacterium spp.; LAB: Lactobacillus/Enterococcus spp; BAC: Bacteroides spp; EREC: Clostridium coccoidesEubacterium rectale group; RREC: Roseburia genus; ATO: Atopobium spp; PRO: Clostridium cluster IX; FPRAU: Faecalibacterium prausnitzii group; DSV: Desulfovibrionales (excluding Lawsonia) and many Desulfuromonales; CHIS: C. histolyticum group. Changes in bacterial growth calculated by comparing the number of a specific bacterial group in the treatment with the number found in a control group, at the same time point.

\section{AUTHOR STATEMENT}

1. Selina BRIGHINA: Investigation, Formal analysis, Data Curation, writing

2. Carlos POVEDA TURRADO: Investigation, Provision of study material, Data Curation

3. Cristina RESTUCCIA: Conceptualization, Validation, Writing - Review \& Editing

4 Gemma WALTON: Validation, Writing - Review \& Editing

5. Biagio FALLICO: Conceptualization, Data curation, Writing - Review \& Editing

6. Maria Jose ORUNA-CONCHA: Resources, Validation, Writing - Review \& Editing

7. Elena ARENA: Conceptualization, Validation, Writing - Review \& Editing 


\section{Declaration of interests}

$\bigotimes$ The authors declare that they have no known competing financial interests or personal relationships that could have appeared to influence the work reported in this paper.

$\square$ The authors declare the following financial interests/personal relationships which may be considered as potential competing interests:

On Behalf of all authors

Biagio Fallico

Highlights:

- GO, MGO and 3-DG withstand in vitro gastrointestinal digestion

- Digested 1,2-dicarbonyl compounds reduce number and activity of gut microorganisms

- For the first time, the role of 3-DG in modifying the gut microbial levels has been shown 
- 1,2-dicarbonyls reduce the levels of Short Chain Fatty Acids produced during fermentation

Table 1. FISH oligonucleotides probes used and bacterial groups studied.

\begin{tabular}{|c|c|c|c|c|}
\hline $\begin{array}{l}\text { Probe } \\
\text { name }\end{array}$ & Sequence (5' to $\left.3^{\prime}\right)$ & $\begin{array}{l}\text { Targed bacterial } \\
\text { group/species }\end{array}$ & $\begin{array}{l}\mathrm{T}_{\mathrm{H}} \\
\left({ }^{\circ} \mathrm{C}\right)\end{array}$ & Reference \\
\hline Non Eub & ACTCCTACGGGAGGCAGC & No bacteria & 35 & $\begin{array}{l}\text { Wallner et } \\
\text { al. (1993) }\end{array}$ \\
\hline Eub338 & GCTGCCTCCCGTAGGAGT & Total bacteria & 35 & $\begin{array}{l}\text { Daims et al. } \\
(1999)\end{array}$ \\
\hline Eub338II & GCAGCCACCCGTAGGTGT & Total bacteria & 35 & $\begin{array}{l}\text { Daims et al. } \\
\text { (1999) }\end{array}$ \\
\hline Eub338III & GCTGCCACCCGTAGGTGT & Total bacteria & 35 & $\begin{array}{l}\text { Daims et al. } \\
(1999)\end{array}$ \\
\hline Bif164 & CATCCGGCATTACCACCC & Bifidobacterium spp. & 35 & $\begin{array}{l}\text { Langen.dijk } \\
\text { et al. (1995) }\end{array}$ \\
\hline Lab158 & GGTATTAGCAYCTGTTTCCA & $\begin{array}{l}\text { Lactobacillus/Enterococcus } \\
\text { spp }\end{array}$ & 35 & $\begin{array}{l}\text { Harmsen et } \\
\text { al. (1999) }\end{array}$ \\
\hline Bac303 & CCAATGTGGGGGACCTT & Bacteroides spp & 35 & $\begin{array}{l}\text { Manz et al. } \\
(1996)\end{array}$ \\
\hline Erec482 & GCTTCTTAGTCARGTACCG & $\begin{array}{l}\text { Clostridium coccoides- } \\
\text { Eubacterium rectale group }\end{array}$ & 35 & $\begin{array}{l}\text { Franks et al. } \\
\text { (1998) }\end{array}$ \\
\hline Rrec584 & TCAGACTTGCCGYACCGC & Roseburia genus & 35 & $\begin{array}{l}\text { Walker et al. } \\
(2005)\end{array}$ \\
\hline Ato291 & GGTCGGTCTCTCAACCC & Atopobium spp & 35 & $\begin{array}{l}\text { Harmsen et } \\
\text { al. (2000) }\end{array}$ \\
\hline Prop853 & ATTGCGTTAACTCCGGCAC & Clostridium cluster IX. & 35 & $\begin{array}{l}\text { Walker et al. } \\
(2005)\end{array}$ \\
\hline Fprau655 & CGCCTACCTCTGCACTAC & $\begin{array}{l}\text { Faecalibacterium prausnitzii } \\
\text { group }\end{array}$ & 35 & $\begin{array}{l}\text { Devereux et } \\
\text { al. (1992) }\end{array}$ \\
\hline \multirow[t]{2}{*}{ DSV687 } & TACGGATTTCACTCCT & $\begin{array}{l}\text { Desulfovibrionales (excluding } \\
\text { Lawsonia) an.d many }\end{array}$ & 35 & $\begin{array}{l}\text { Hold et al. } \\
(2003)\end{array}$ \\
\hline & & Desulfuromonales & & \\
\hline Chis150 & TTATGCGGTATTAATCTYCCTTT & C. histolyticum group & 35 & $\begin{array}{l}\text { Franks et al. } \\
\text { (1998) }\end{array}$ \\
\hline
\end{tabular}




\section{Journal Pre-proofs}

Table 2. Residual levels percentage (average value and for each donor) of 1,2 dicarbonyl compounds in a $\mathrm{pH}$-controlled anaerobic fermentation vessels in presence or absence of gut microflora.

\begin{tabular}{|c|c|c|c|c|c|}
\hline & & & Time (h) & & \\
\hline $\begin{array}{l}\text { Initial } \\
\text { level }\end{array}$ & Residual level \% & $0.1^{\mathrm{a}}$ & 4 & 8 & 24 \\
\hline \multirow{5}{*}{ 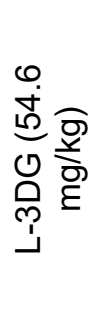 } & Without faecal slurry & $107.2 \pm 0.5 \mathrm{Aa}$ & 101.1 $\pm 0.6 \mathrm{Ab}$ & $80.3 \pm 0.3 \mathrm{Ac}$ & $67.6 \pm 0.7 \mathrm{Ad}$ \\
\hline & + faecal slurry & $64.3 \pm 23.3 \mathrm{Aa}$ & $54.8 \pm 13.1 \mathrm{Ba}$ & $17.3 \pm 11.5 \mathrm{Bb}$ & $0.53 \pm 0.9 \mathrm{Bc}$ \\
\hline & Donor1 & 57.3 & 56.6 & 30.1 & n.d \\
\hline & Donor2 & 90.3 & 66.8 & 13.7 & 1.6 \\
\hline & Donor3 & 45.2 & 40.8 & 7.9 & nd \\
\hline \multirow{5}{*}{ 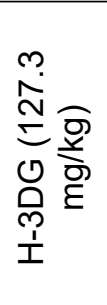 } & Without faecal slurry & $126.7 \pm 10.0 \mathrm{Aa}$ & 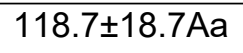 & $136.0 \pm 36.0 \mathrm{Aa}$ & $114.6 \pm 14.6 \mathrm{Aa}$ \\
\hline & + faecal slurry & $89.4 \pm 7.1 \mathrm{Ba}$ & $67.3 \pm 6.0 \mathrm{Bb}$ & $53.5 \pm 16.2 \mathrm{BC}$ & $2.03 \pm 2.1 \mathrm{Bd}$ \\
\hline & Donor1 & 83.9 & 59.4 & 68.8 & n.d \\
\hline & Donor2 & 98.8 & 71.3 & 59.0 & 1.4 \\
\hline & Donor3 & 85.4 & 71.4 & 32.7 & 4.7 \\
\hline \multirow{5}{*}{ 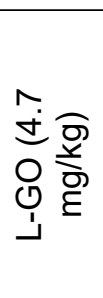 } & Without faecal slurry & $130.4 \pm 16.5 \mathrm{Aa}$ & $58.8 \pm 3.4 \mathrm{Ab}$ & $30.2 \pm 6.3 \mathrm{Ac}$ & $20.5 \pm 3.5 \mathrm{Ac}$ \\
\hline & + faecal slurry & $113.9 \pm 13.8 \mathrm{Aa}$ & $62.1 \pm 5.3 \mathrm{Ab}$ & $37.1 \pm 7.9 \mathrm{Ac}$ & $3.89 \pm 2.92 \mathrm{Bd}$ \\
\hline & Donor1 & 117.7 & 63.05 & 27.76 & 5.95 \\
\hline & Donor2 & 96.40 & 55.61 & 36.19 & 5.71 \\
\hline & Donor3 & 127.60 & 67.71 & 45.62 & 0.97 \\
\hline
\end{tabular}

\begin{tabular}{|c|c|c|c|c|c|}
\hline \multirow{5}{*}{ 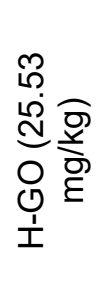 } & Without faecal slurry & $49.6 \pm 10.4 \mathrm{Ba}$ & $46.4 \pm 9.8 \mathrm{Ba}$ & $32.4 \pm 0.28 \mathrm{Ab}$ & $6.5 \pm 0.2 A c$ \\
\hline & + faecal slurry & $115.8 \pm 14.5 \mathrm{Aa}$ & $64.5 \pm 6.74 \mathrm{Ab}$ & $31.3 \pm 5.39 \mathrm{Ac}$ & $9.42 \pm 2.50 \mathrm{Ad}$ \\
\hline & Donor1 & 116.06 & 67.47 & 24.97 & 7.57 \\
\hline & Donor2 & 99.98 & 55.72 & 31.51 & 12.75 \\
\hline & Donor3 & 137.18 & 70.42 & 37.35 & 7.94 \\
\hline \multirow{5}{*}{ 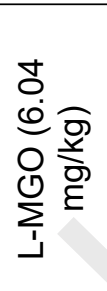 } & Without faecal slurry & $90.2 \pm 3.4 \mathrm{Aa}$ & $9.9 \pm 1.0 \mathrm{Ab}$ & $0.5 \pm 0.0 \mathrm{Bc}$ & n.d \\
\hline & + faecal slurry & $91.2 \pm 26.3 \mathrm{Aa}$ & $46.2 \pm 21.0 \mathrm{Ab}$ & $21.9 \pm 18.7 \mathrm{Ac}$ & n.d \\
\hline & Donor1 & 119.70 & 74.24 & 44.27 & n.d \\
\hline & Donor2 & 59.35 & 31.24 & 1.12 & n.d \\
\hline & Donor3 & 94.42 & 33.14 & 20.25 & n.d \\
\hline
\end{tabular}

\begin{tabular}{|c|c|c|c|c|c|}
\hline \multirow{5}{*}{ 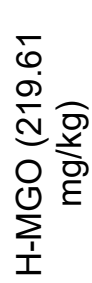 } & Without faecal slurry & $127.2 \pm 15.3 \mathrm{Aa}$ & $84.1 \pm 3.6 \mathrm{Ab}$ & $53.8 \pm 5.0 \mathrm{Ac}$ & $36.1 \pm 1.0 \mathrm{Ad}$ \\
\hline & + faecal slurry & $111.9 \pm 9.03 \mathrm{Aa}$ & $68.4 \pm 15.9 \mathrm{Ab}$ & $35.5 \pm 25.7 \mathrm{Ac}$ & $14.4 \pm 11.7 \mathrm{Bd}$ \\
\hline & Donor1 & 116.06 & 47.77 & 50.66 & 15.73 \\
\hline & Donor2 & 99.98 & 74.27 & 54.55 & 27.17 \\
\hline & Donor3 & 119.51 & 83.14 & 1.25 & 0.16 \\
\hline
\end{tabular}

a $0.1,10$ min. Data expressed as the mean \pm standard deviation. In each column, values followed by different capital letters within the same dicarbonyl compounds level and time and are significantly different according to Fisher's least significant difference test $(p \leq 0.05)$. In each row, values followed by different lowercase letters are significantly different according to Fisher's least significant difference test $(p \leq 0.05)$ 

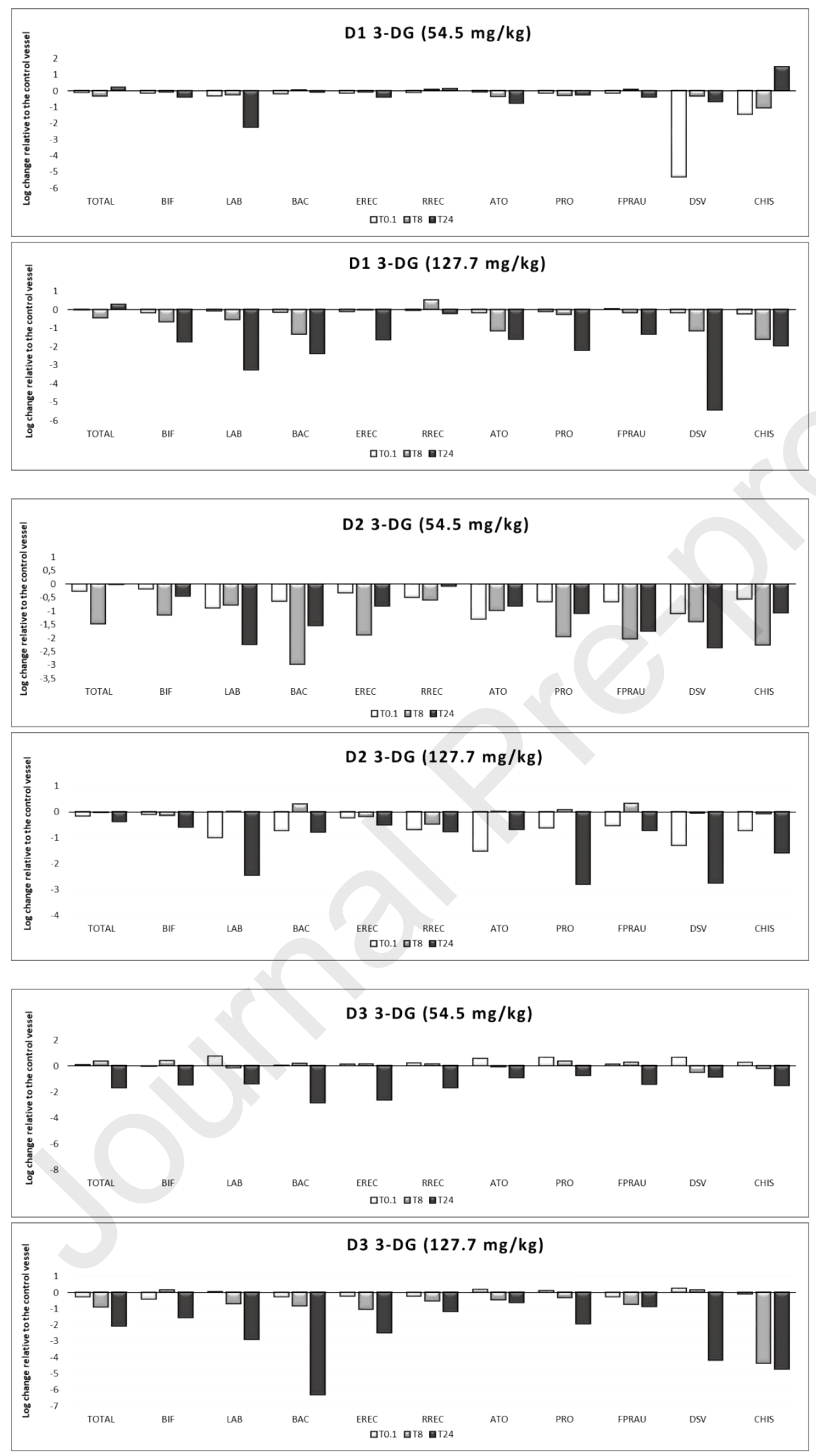

Fig. 1. Influence of low $(54.5 \mathrm{mg} / \mathrm{kg})$ and high $(127.7 \mathrm{mg} / \mathrm{kg})$ levels of 3-DG on the gut microbiota of different donors (D1, D2, D3) in a pH-controlled anaerobic fermentation vessels $(1 \%$ faecal slurry, $\mathrm{n}=1$ ) quantified using fluorescence in situ hybridisation. Samples were collected at time (T) 0.1 (10 min), 8, and 24 h. Bacterial name: TOTAL: Total bacteria; BIF: Bifidobacterium spp.; 


\section{Journal Pre-proofs}

LAB: Lactobacillus/Enterococcus spp; BAC: Bacteroides spp; EREC: Clostridium coccoidesEubacterium rectale group; RREC: Roseburia genus; ATO: Atopobium spp; PRO: Clostridium cluster IX; FPRAU: Faecalibacterium prausnitzii group; DSV: Desulfovibrionales (excluding Lawsonia) and many Desulfuromonales; CHIS: C. histolyticum group. Changes in bacterial growth calculated by comparing the number of a specific bacterial group in the treatment with the number found in a control group, at the same time point. 

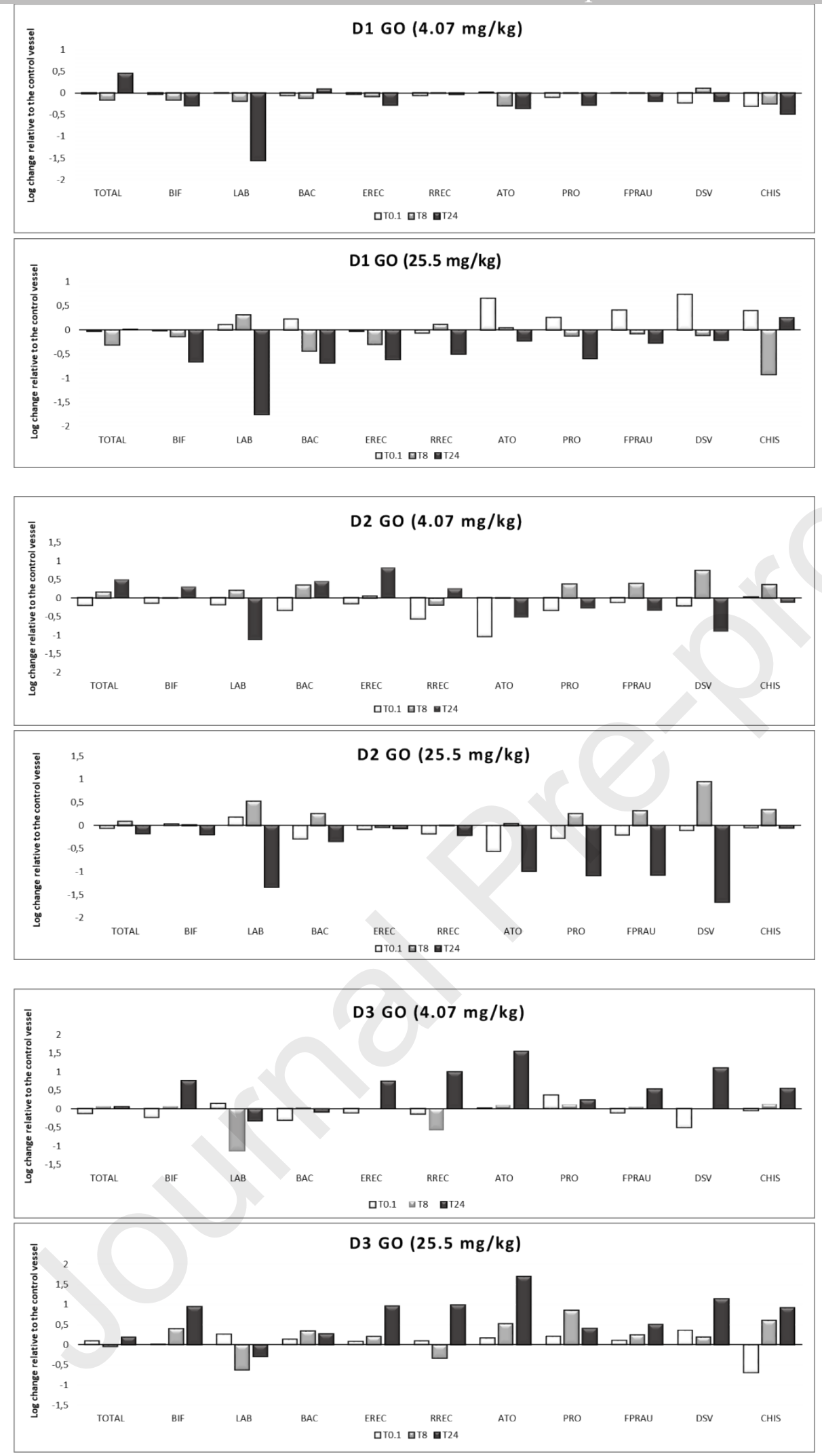

Fig. 2. Influence of low $(4.07 \mathrm{mg} / \mathrm{kg})$ and high $(25.5 \mathrm{mg} / \mathrm{kg})$ levels $\mathrm{GO}$ on the gut microbiota of different donors (D1, D2, D3) in a pH-controlled anaerobic fermentation vessels (1\% faecal slurry, $\mathrm{n}=1$ ) quantified using fluorescence in situ hybridisation. Samples were collected at time (T) 0.1 (10 min), 8, and 24 h. Bacterial name: TOTAL: Total bacteria; BIF: Bifidobacterium spp.; LAB: Lactobacillus/Enterococcus spp; BAC: Bacteroides spp; EREC: Clostridium coccoidesEubacterium rectale group; RREC: Roseburia genus; ATO: Atopobium spp; PRO: Clostridium cluster IX; FPRAU: Faecalibacterium prausnitzii group; DSV: Desulfovibrionales (excluding 
Lawsonia) and many Desulfuromonales; CHIS: C. histolyticum group. Changes in bacterial growth calculated by comparing the number of a specific bacterial group in the treatment with the number found in a control group, at the same time point.
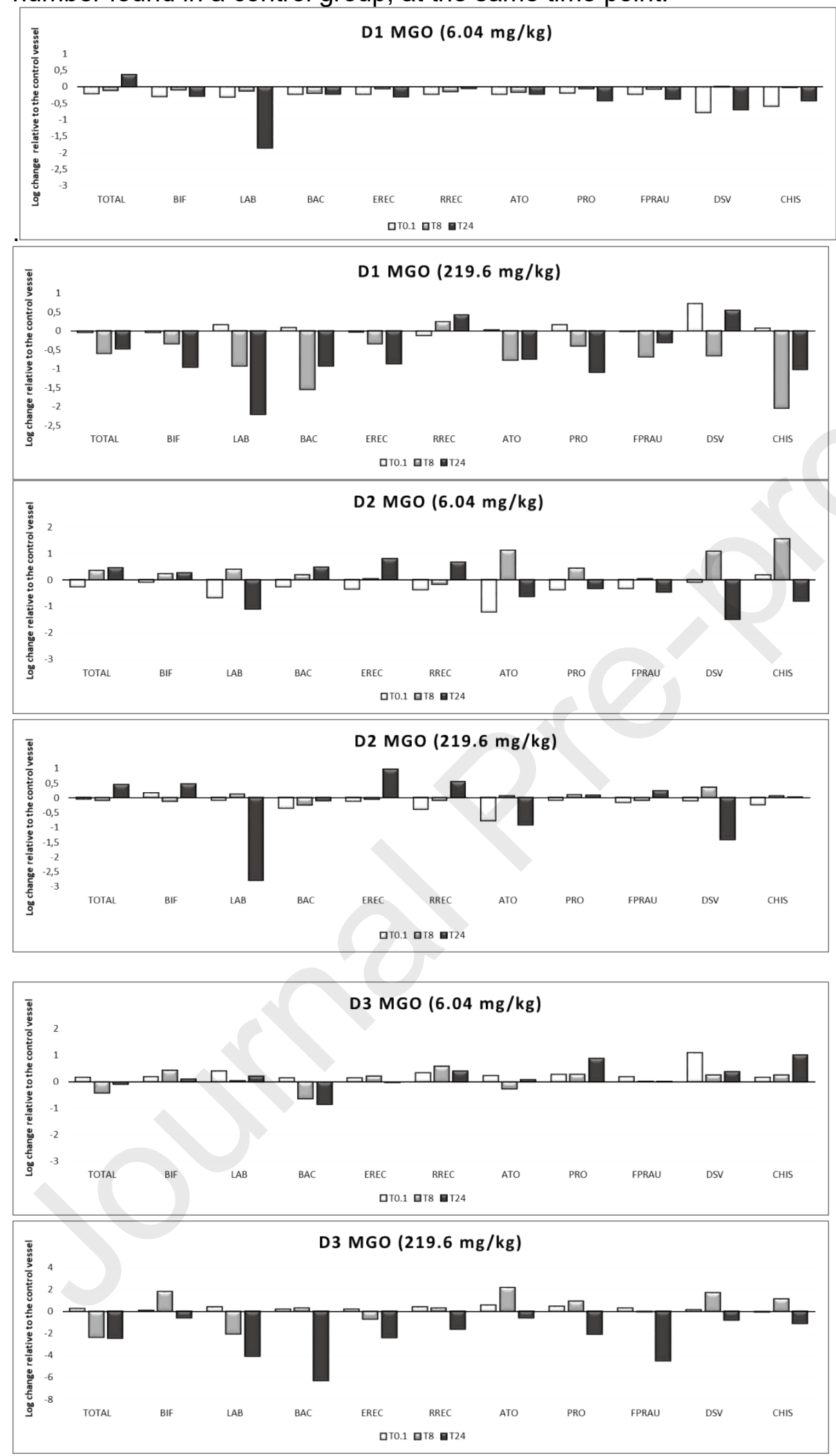

Fig. 3. Influence of low $(6.04 \mathrm{mg} / \mathrm{kg})$ and high $(219.6 \mathrm{mg} / \mathrm{kg})$ levels of MGO on the gut microbiota of different donors (D1, D2, D3) in a pH-controlled anaerobic fermentation vessels $(1 \%$ faecal slurry, $\mathrm{n}=1$ ) quantified using fluorescence in situ hybridisation. Samples were collected at time (T) 0.1 (10 min), 8, and 24 h. Bacterial name: TOTAL: Total bacteria; BIF: Bifidobacterium spp.; LAB: Lactobacillus/Enterococcus spp; BAC: Bacteroides spp; EREC: Clostridium coccoides- 


\section{Journal Pre-proofs}

Eubacterium rectale group; RREC: Roseburia genus; ATO: Atopobium spp; PRO: Clostridium cluster IX; FPRAU: Faecalibacterium prausnitzii group; DSV: Desulfovibrionales (excluding Lawsonia) and many Desulfuromonales; CHIS: C. histolyticum group. Changes in bacterial growth calculated by comparing the number of a specific bacterial group in the treatment with the number found in a control group, at the same time point. 